\title{
Evaluation of quality status and detection of adulterants in selected commercial pickles and chutneys based on consumer attitude and laboratory analysis
}

\author{
A. $\operatorname{Rahman}^{1^{*}}$, M. S. Kayshar ${ }^{2}$, M. Saifullah ${ }^{3}$ and M. B. Uddin ${ }^{4}$ \\ ${ }^{184}$ Department of Food Technology and Rural Industries, Bangladesh Agricultural University, Mymensingh-2202, \\ ${ }^{2}$ Department of Food Engineering and Technology, Sylhet Agricultural University, Sylhet-3100 and ${ }^{3}$ Department of \\ Process and Food Engineering, University of Putra, Malaysia. *E-mail: muhammad@bau.edu.bd
}

\begin{abstract}
Quality of selected commercial pickles and chutneys were evaluated by conducting a baseline survey on the consumer attitude towards the products and analyzing the selected products for adulterants and performing sensory evaluation. The pickle and chutney samples were analyzed in selected accredited laboratories for the physicochemical parameters such as fluid portion percent by mass of the net mass, acidity as citric acid (\% $\mathrm{mg} / \mathrm{gm}$ ), sodium benzoate $(\mathrm{mg} / \mathrm{Kg})$, arsenic $(\mathrm{mg} / \mathrm{Kg})$, Lead $(\mathrm{mg} / \mathrm{Kg})$, copper $(\mathrm{mg} / \mathrm{Kg})$, zinc $(\mathrm{mg} / \mathrm{Kg})$, tin $(\mathrm{mg} / \mathrm{Kg})$. The result showed that all the commercial samples have fluid portion within the BSTI range except samples 'D' and 'E' and all the heavy metals were below the detection level. In case of samples ' $A$ ' and ' $B$ ' acidity was lower than the optimum value. However, preservative used in the samples are much higher than that of accepted level. From the sensory and organoleptic evaluation it was found that the average scores obtained by the pickles and chutney products for colour \& texture, taste \& flavor, absence of defects and total scores were satisfactory in comparison to BSTI standard. Concerning to total energy content mango pickles sample ' $A$ ' has greater energy content than sample ' $B$ '. Among chutneys sample ' $C$ ' has greater energy content where sugar is the main source of energy. In conclusion, commercial pickle and chutney may be recommended as safe and fit for consumption as the values for quality and sensory parameters comply with the BSTI standards. The current views of consumers about the quality of commercial pickle and chutney obtained from the baseline survey has been proved wrong after comparing analyzed values with those standards.
\end{abstract}

Keywords: Food quality, Adulteration, Pickles, Chutney

\section{Introduction}

Pickle is one of the oldest and most successful methods of food preservation known to human. The optimization of pickle quality depends on maintenance of proper acidity, salt concentration, temperature and sanitary conditions. Pickle products add spice to meals and snacks. The skillful blending of spice, sugar and oil with fruit and vegetable gives crisp, firm texture and pungent, sweet-sour flavor. Pickles serve as appetizers and help in digestion by aiding flow of gastric juices (Askar \& Treptow, 1993). For a good quality pickle having a fairly long shelf life should contain salt over $12 \%$, best is above $15 \%$, acidity $1.2 \%$ as citric acid, moisture content below $50 \%$, oil should be sufficient to cover the top completely to create anaerobic conditions and to check the growth of aerobic microorganisms (aerobic bacteria, moulds and yeasts), for sweet pickle $26.25 \%$ sugar and preservative should be mixed well in optimal level for example sodium benzoate 250ppm (Usha Rani et al., 1992). Chutney is prepared in the similar way like jam except that spices, vinegar and salt are added. The quality of chutney depends to a large extent on its cooking which should be done for a long time at a temperature below the boiling point. To ensure proper thickening, cooking is done to the consistency of jam (65\% solid) to avoid fermentation. The high sugar content and acid preserves the chutney after a jar has been opened. Spices also have a preservative effect, in addition to contributing to the flavour of the chutney (Pruthi and Bedekar, 1963). Rising liberalization of agro-industrial markets and the world-wide integration of food supply chains require new approaches and systems for assuring food safety. When a consumer expresses himself about the quality of commercial fruit products, he/she will most likely do it in his own words. He will say "it is good" or "it is not good", "it is tasty" or "it is tasteless". This standpoint represents to the scientist a first established fact. Based on this short consumer's statement he has then to establish a correlation between analytical values and the consumer's judgment. The objective evaluation of the quality of commercial pickles and chutney is a difficult task. This is mainly due to the fact that every single person is not necessarily influenced by the same sensory attributes and that the quality scale may vary strongly 
from one person to another (Hui, 2004). This study is beneficial in many aspects. Because this study had the objectives to accomplish quality assessment, detect and determine adulterants of commercial fruit pickles and chutneys available in local market of Mymensingh under different brand names thus emphasizes the proper grading and standardization which determines their price.

\section{Materials and Methods}

Before starting laboratory experiment a comprehensive baseline survey was conducted to know consumer attitude towards commercial pickled products covering the people of different sections of society such as academician, scientists, doctors, researchers, food processors, food factory managers, traders and consumers using a comprehensive questionnaire. One thousand questionnaires were distributed among the consumers and filled questionnaires were received from them. Quantitative and Qualitative data were converted into scoring wherever necessary. Data obtained from the respondents were first transferred to a master sheet, then compiled, coded, tabulated and analyzed in accordance with the objectives of the study.

For laboratory experiments commercial pickles and chutney samples were collected from local market of Mymensingh city. Samples were coded to avoid biasness like A, B, C, D and E representing Mango Pickle-1, Mango Pickle-2, Sweet Jujube Chutney-1, Sweet Jujube Chutney-2 and Tamarind Chutney, respectively. These samples were analyzed in selected accredited laboratories to determine important physicochemical parameters to assess the quality and to determine adulterants in products. Short description of procedures of all the tests is given below.

\section{Determination of fluid portion by net mass}

At first a clean and dry muslin cloth is weighed. Then the bottle with the sample is weighed. The sample is then poured on the cloth and the strained fluid portion is collected in a pot of known weight. The sample can be stirred several times and sometime little pressure can be applied by hand to facilitate straining. After 1-2hour when the straining is complete the product is removed and the weight of cloth is taken and the difference is recorded as $A$. The pot is weighed and recorded the difference as B. Weight of empty bottle is taken and the difference is recorded as the sample weight (say S). Percent fluid portion can be calculated with the following equation.

Calculation: Percent fluid portion by net mass $=\frac{(A+B) 100}{S}$

Where: $A=$ Difference between dry cloth and the wet cloth after strained

$\mathrm{B}=$ Difference between empty pot and pot with strained sample

$\mathrm{S}=$ Sample weight

\section{Estimation of total Sugar}

Total sugar was estimated according to the methods of Rangana (2005). Sugar content of products was estimated by determining the volume of unknown sugar solution of commercial pickles and chutney required for complete reduction of standard Fehling's solution.

\section{Determination of Sodium benzoate}

In $\mathrm{NaCl}$ solution of sample, the benzoic acid present is converted into water soluble sodium benzoate by the addition of $\mathrm{NaOH}$. When the sodium benzoate solution is acidified with excess $\mathrm{HCl}$, water insoluble benzoic acid is formed which is extracted with chloroform. The chloroform is removed by evaporation and the residue containing benzoic acid is dissolved in alcohol and then titrated with standard $\mathrm{NaOH}$.

Calculation: Benzoic Acid (ppm) $=\frac{61000000 \times \mathrm{NV}}{\text { VIW }}$

Where, $\mathrm{N}, \mathrm{V}, \mathrm{V}_{1}$ and $\mathrm{W}$ denote normality of the standard sodium hydroxide solution, volume of standard sodium hydroxide solution, volume of filtrate taken and mass in $\mathrm{g}$ of the material respectively. 


\section{Determination of crude protein by Kjeldahl method}

The wet oxidation of sample and the conversion of protein nitrogen into ammonium sulphate. The decomposition of ammonium sulphate while strong alkali and distillation of the ammonia evolved into saturated boric acid which holds the ammonia. The titration of the ammonia with standard acid. The calculation of the percentage of protein in the sample using protein factor.

Calculation: $\%$ Protein $=(T \times 1.4 \times 100 \times 100 / 5) \times$ protein factor; $\quad$ Where,$\quad T=$ Titer volume

\section{Determination of crude fat by Soxhlet apparatus method}

$5 \mathrm{gm}$ sample is weighed and transferred into a thimble. Then the thimble was placed in the extraction tube. About $60-75 \mathrm{ml}$ petroleum ether is taken in the tarred flask and connected the extraction tube to the flask. Then attached and regulated the temperature around $90^{\circ} \mathrm{C} \cdot \mathrm{A}$ loose plug of cotton was placed at the top of the condenser to minimize solvent loss. the Extraction was continued for 8 hours. After the extraction is over, remove the thimble from the extractor, connected the extraction tube again and heated the solvent. The solvent was then recovered. The ether in the flask was evaporated by placing it on the steam bath. The flask was dried in the oven at $110^{\circ} \mathrm{C}$ to constant weight.

Calculation: \% Crude fat $=\frac{(X-Y) 100 \times 63 \%}{\text { Samplewt. }}$

Where, $X=$ wt. of sample dish; $Y=(W t$. of dish + crude fat $)$; Wt. of crude fat $=(X-Y)$

Calculation: Total Calorie $=$ Sugar $(\mathrm{gm}) \times 4+$ Fat $(\mathrm{gm}) \times 9+$ Protein $(\mathrm{gm}) \times 4$

\section{Determination of acidity as citric acid}

A known weight of sample is dissolved in a known volume of distilled water. From this an aliquot is taken and titrate with $0.1 \mathrm{~N} \mathrm{NaOH}$ using phenolphthalein as indicator. The end point is denoted by the appearance of pink color.

Calculation: \% Citric acid $=\frac{\text { Titre } \times \text { Normality of alkali } \times \text { Meq. wt. of acid } \times 100}{\text { Wt. of sample }}$

Where: meq= milliequivalent; milliequivalent wt. of citric acid $=0.06404$

Determination of heavy metals as (As, $\mathrm{Pb}, \mathrm{Cu}, \mathrm{Zn} \mathrm{\&} \mathrm{Sn)}$

Atomic Absorption Spectrophotometry after microwave digestion (NMKL-AOAC Method)

This method is applicable to determination of $\mathrm{Zn}$ and $\mathrm{Cu}$ in a variety of foods by microwave digestion and flame atomic absorption spectrophotometry (FAAS), and $\mathrm{Pb}$ by microwave digestion and graphite furnace atomic absorption spectroscopy (GFAAS). Method is capable of determining these elements at concentrations above approximately $\mathrm{Pb}(0.4), \mathrm{Zn}(4)$ and $\mathrm{Cu}(3) \mathrm{mg} / \mathrm{kg}$. Products are digested with $\mathrm{HNO}_{3}$ and $\mathrm{H}_{2} \mathrm{O}_{2}$ under pressure in a closed vessel heated by microwave. Solution is diluted with $\mathrm{H}_{2} \mathrm{O}$. $\mathrm{Pb}$ is determined by GFAAS, $\mathrm{Zn}$ and $\mathrm{Cu}$ are determined by FAAS. Materials are digested with $\mathrm{HNO}_{3}$ and then $\mathrm{HCl}$ and are diluted. Aqueous $\mathrm{KCl}$ is added to test solutions and standards to reduce positive instrument interference. $\mathrm{Sn}$ in determined by AAS at $235.5 \mathrm{~nm}$ with oxidizing $\mathrm{N}_{2} \mathrm{O}-\mathrm{C}_{2} \mathrm{H}_{2}$ flame. When running replicates, the average of the results should be given with 3 significant figures. Method is not applicable to foods with a fat content $\geq 40 \%$. The details of the above methods are available in AOAC (986.15), AOAC (972.25), AOAC (973.34), AOAC (971.20), and AOAC (985.16) for the determination of arsenic, lead, copper, zinc and tin in food products respectively.

The sensory and organoleptic evaluation was done by a panel of ten experts to score colour and texture, taste and flavour and absence of defects by the method described in Bangladesh standard specification for pickles and chutney (third revision appendix-C, BDS 520:2012) and compared with existing BSTI standard score for this parameters. 


\section{Results and Discussion}

This study was performed to assess the quality of commercial fruit pickles and chutney by analyzing their physicochemical parameters, heavy metal content, preservative content, and by performing sensory and organoleptic evaluation.

\section{Baseline survey results}

Baseline survey shows the public perception towards quality status of commercial pickles and chutneys. The responses of status and adulterants used are shown in Table 1 and Table 2.

Table 1. Status of adulteration in selected processed pickles $\&$ chutneys

\begin{tabular}{|c|c|c|c|c|c|c|c|}
\hline $\begin{array}{c}\text { SI. } \\
\text { No }\end{array}$ & $\begin{array}{c}\text { Name of } \\
\text { product }\end{array}$ & $\begin{array}{c}\text { Total respondent } \\
\text { Nos. }\end{array}$ & \multicolumn{2}{|c|}{ Responses, Nos } & \multicolumn{2}{|c|}{ Valid \% } & Remarks \\
\cline { 4 - 7 } & Adulterated & Not-adulterated & Yes & No & $\begin{array}{c}\text { All commercial } \\
\text { pickles \& chutney are } \\
\text { highly adulterated }\end{array}$ \\
\hline 1. & Pickles \& & 990 & 907 & 83 & 91.60 & 8.40 \\
\hline
\end{tabular}

Table 2. Adulterants used, status of quality \& preventive measures to control adulteration in commercial pickles \& chutneys

\begin{tabular}{|c|c|c|c|c|c|c|}
\hline $\begin{array}{l}\text { SI } \\
\text { no. }\end{array}$ & Respondent view & $\begin{array}{c}\text { Total } \\
\text { respondent }\end{array}$ & Type of adulterants & $\begin{array}{l}\text { Respondent } \\
\text { Nos. }\end{array}$ & $\begin{array}{c}\text { Percent } \\
\text { respondent }\end{array}$ & Remark \\
\hline \multirow{6}{*}{1.} & \multirow{6}{*}{ Adulterants used } & \multirow{6}{*}{970} & Not-permitted artificial sweeteners & 369 & 38.04 & \\
\hline & & & Excessive permitted preservatives & 315 & 32.47 & \\
\hline & & & Harmful food colours & 727 & 74.95 & First \\
\hline & & & Low grade fruits & 681 & 70.21 & Second \\
\hline & & & Harmful preservatives & 407 & 41.96 & Third \\
\hline & & & Others & 24 & 2.47 & \\
\hline \multirow[b]{4}{*}{2.} & \multirow[b]{4}{*}{$\begin{array}{l}\text { Status of quality } \\
\text { and safety }\end{array}$} & \multirow[b]{4}{*}{993} & Are healthful for the consumers & 56 & 5.64 & \\
\hline & & & Are harmful for the consumers & 543 & 54.68 & First \\
\hline & & & Consumers should eat it & 103 & 10.37 & Third \\
\hline & & & Consumers should not eat it & 291 & 29.31 & Second \\
\hline \multirow{6}{*}{3.} & \multirow{6}{*}{$\begin{array}{l}\text { Preventive } \\
\text { measures to } \\
\text { control } \\
\text { adulteration }\end{array}$} & \multirow{6}{*}{970} & $\begin{array}{l}\text { Enforcing law and imposing } \\
\text { punishment }\end{array}$ & 785 & $80.93 \%$ & Second \\
\hline & & & $\begin{array}{l}\text { Social motivation of food } \\
\text { processor }\end{array}$ & 572 & 58.97 & \\
\hline & & & Adopting BSTI standards & 798 & 82.27 & First \\
\hline & & & $\begin{array}{l}\text { Social motivation of food } \\
\text { consumers }\end{array}$ & 727 & 74.95 & Third \\
\hline & & & $\begin{array}{l}\text { Strengthening supervision by legal } \\
\text { authority }\end{array}$ & 603 & 62.16 & \\
\hline & & & Others & 87 & 8.97 & \\
\hline
\end{tabular}

The baseline survey results in table $1 \& 2$ shows that consumers view towards commercial pickles and chutneys is negative. Among the respondents, $91.6 \%$ believe that commercial pickles and chutneys are adulterated and $74.95 \%$ marked harmful food colors as main adulterants and $54.68 \%$ of respondents recommended them harmful for the consumers. Finally $82.27 \%$ respondents suggested adopting BSTI standard to uplift quality status and to prevent adulteration in commercial pickles and chutney.

\section{Physicochemical analysis}

The values of the physicochemical parameters determine the quality status of the commercial pickles and chutney. The results of physicochemical parameters for selected commercial pickles and chutney are shown in Table 3. 
Table 3. Physicochemical parameters of commercial of pickle and chutney samples

\begin{tabular}{|c|c|c|c|c|c|c|c|}
\hline \multirow{2}{*}{$\begin{array}{l}\text { SI. } \\
\text { No }\end{array}$} & \multirow[b]{2}{*}{ Tested parameters } & \multicolumn{5}{|c|}{ Tested results by BSTI } & \multirow{2}{*}{$\begin{array}{c}\text { Reference } \\
\text { (BSTI) } \\
\text { Standard }\end{array}$} \\
\hline & & Sample A & Sample B & Sample C & Sample D & Sample E & \\
\hline 1. & $\begin{array}{l}\text { Fluid portion \% by mass of the net } \\
\text { mass }\end{array}$ & 17.60 & 24.7 & 18.50 & 34.1 & 35.40 & 33.3 \\
\hline 2. & Acidity as citric acid, \%mg/mg & 1.04 & 0.33 & 2.92 & 2.73 & 4.01 & 1.2 \\
\hline 3. & Sodium benzoate, $\mathrm{mg} / \mathrm{Kg}$ & 418.36 & 348.96 & 211.80 & 181.68 & 211.02 & 250 \\
\hline 4. & Arsenic (as As), mg/kg & $\mathrm{BDL}^{*}$ & $\mathrm{BDL}^{*}$ & $\mathrm{BDL}^{*}$ & $\mathrm{BDL}^{*}$ & $\mathrm{BDL}^{*}$ & - \\
\hline 5. & Lead (as pb), mg/kg & $\mathrm{BDL}^{*}$ & $\mathrm{BDL}^{*}$ & $\mathrm{BDL}^{*}$ & $\mathrm{BDL}^{*}$ & $\mathrm{BDL}^{*}$ & 0.3 \\
\hline 6. & Copper (as Cu), mg/kg & $\mathrm{BDL}^{*}$ & $\mathrm{BDL}^{*}$ & $\mathrm{BDL}^{*}$ & $\mathrm{BDL}^{*}$ & $\mathrm{BDL}^{*}$ & 5.0 \\
\hline 7. & Zinc (as Zn), $\mathrm{mg} / \mathrm{kg}$ & $\mathrm{BDL}^{*}$ & $\mathrm{BDL}^{*}$ & $\mathrm{BDL}^{*}$ & $\mathrm{BDL}^{*}$ & $\mathrm{BDL}^{*}$ & 5.0 \\
\hline 8. & Tin (as Sn), mg/kg & $\mathrm{BDL}^{*}$ & $\mathrm{BDL}^{*}$ & $\mathrm{BDL}^{*}$ & $\mathrm{BDL}^{*}$ & $\mathrm{BDL}^{*}$ & 250 \\
\hline
\end{tabular}

Note: ${ }^{*} \mathrm{BDL}=$ below detection level

Pickles and chutneys with higher fluid portion than that of reference value of BSTI are more susceptible to microbial contamination and have shorter storage life in comparison to products with lower fluid portion. From Table 3, it is seen that commercial chutney samples ' $D$ ' and ' $E$ ' have fluid portion slightly higher than that of reference value of BSTI. Higher fluid portion also accelerates rancidity and results in development of off-flavor (Usha et al., 1992) when studied on quality standards of Indian commercial pickle. From Table 3, it is observed that samples ' $A$ ' and ' $B$ ' have acidity value lower than the reference value of BSTI. Acidity of pickle and chutney samples decreases with increasing storage period. Moisture, ash and vitamin-C content of processed pickles and chutneys also reduced with decreasing acidity. It means that samples ' $A$ ' and ' $B$ ' were manufactured before samples ' $C$ ', ' $D$ ' and ' $E$ ' or the amount of fermentable sugar was low in the fresh fruit, resulting in low production of lactic acid; or most of the sugars have been washed off during desalting. At low acidity preservative action of sodium benzoate is reduced. The same results were described by (Siddanna, 2010) during documentation of pickles and development of dehydrated mango pickle mix. The quantity of sodium benzoate required depends on the nature of the product to be preserved, particularly its acidity. According to BSTI, pickle and chutney having $\mathrm{p}^{\mathrm{H}}$ below 3.5 which is the optimum range, addition of $250 \mathrm{ppm}$ sodium benzoate is found to be sufficient. Pickle and chutney samples with lower acidity require higher concentration of sodium benzoate. From the Table 3, it is seen that samples ' $A$ ' and ' $B$ ' have lower acidity due to content of higher concentration of sodium benzoate. In case of other three samples ' $C$ ', ' $D$ ' and ' $E$ ', acidity is higher and thus the lower concentration of sodium benzoate $(250 \mathrm{ppm})$ is sufficient to preserve the products. Similar results are shown by (Vibha-Verma and Lokendra-Singh, 2005) during screening of different doses of preservatives and spices in pickles in relation to the shelf-life. Here the estimated amounts of $\mathrm{As}, \mathrm{Pb}, \mathrm{Cu}$, $\mathrm{Zn}$ and $\mathrm{Sn}$ from all the examined commercial samples remained below the respective recommended limit. From the human health point of view, there was no health risk for consumers due to intake of individual heavy metal. However, there is potential health risk to highly exposed consumers. The variation in heavy metal concentrations for all types of analyzed foodstuffs could be due to variable capabilities of absorption and accumulation of heavy metals. Similar report provided by (Siddique et al., 1987) when studied copper, lead, tin and zinc contents in canned and bottled fruit and fruit products.

\section{Sensory and organoleptic properties}

Consumer is able to make a statement on sensory aspects such as shape, color, texture, juiciness, firmness, taste and aroma. These parameters are without any doubt useful, since they are easy to evaluate in real time on sorting lines. On top of that, they are determinant in consumer's perception about the product. The results for sensory evaluation are shown in Table 4. 
Table 4. Average score for sensory parameters

\begin{tabular}{|l|c|c|c|c|c|c|}
\hline \multirow{2}{*}{\multicolumn{1}{|c|}{ Factors }} & \multicolumn{2}{|c|}{ Average score for commercial pickle and chutney Samples } & \multicolumn{2}{c|}{ BSTI } \\
\cline { 2 - 6 } & A & B & C & D & E & 20 standard range \\
\hline Colour \& Texture & 20.2 & 21 & 20.4 & 20 & 20.4 & $20-25$ \\
\hline Taste \& flavour & 40.2 & 39.8 & 39.4 & 38.8 & 39.4 & $40-50$ \\
\hline Absence of defects & 20.8 & 20.6 & 21 & 21.2 & 20.8 & $20-25$ \\
\hline Total score & 81.2 & 81 & 80.4 & 80 & 80.6 & $80-85$ \\
\hline
\end{tabular}

The Table 4 showed that all the commercial pickles and chutney obtained satisfactory sensory scores and it was within the BSTI standard range which indicated that there were slight variation in the shades of characteristic colour of each type of product and the texture tending to be tough but not very hard. But practically uniform colour and good texture, not unduly hard or tough; shall be free from development of softening to the extent that they break up during storage or transport. Avoiding over cooking during processing, use of excessive ground spices, adding too much sugar or too strong salt solution could improve overall colour and texture of the product (Usha et al., 1992).

\section{Energy content of commercial pickles and chutney}

The amount of fat, sugar and protein content present in the selected commercial pickles and chutney determines the energy value.

Table 5. Energy content of the pickles and chutney samples per serving (20gm)

\begin{tabular}{|c|l|c|c|c|c|c|}
\hline \multirow{2}{*}{$\begin{array}{c}\text { Sl. } \\
\text { No }\end{array}$} & Tested parameters & \multicolumn{4}{|c|}{ Commercial pickle and chutney samples } \\
\cline { 2 - 6 } & & $\mathrm{A}$ & $\mathrm{B}$ & $\mathrm{C}$ & $\mathrm{D}$ & $\mathrm{E}$ \\
\hline 1. & Total sugar $(\mathrm{gm})$ & 7.14 & 5.5 & 16.25 & 13.56 & 13.19 \\
\hline 2. & Fat (gm) & 4.28 & 4 & 0.30 & 0.05 & 0.055 \\
\hline 3. & Protein (gm) & 0.1 & 0.15 & 0.50 & 0.132 & 0.584 \\
\hline 4. & Total energy (Calorie) & 67.48 & 58.60 & 65.98 & 55.22 & 55.60 \\
\hline
\end{tabular}

Note: Energy values are computed

From Table 5, it is seen that between the mango pickles sample ' $A$ ' has greater energy content than sample ' $B$ ' due to high sugar content where oil added in the mango pickles is the main energy source. Among chutneys sample ' $C$ ' has greater energy content where sugar is main source of energy. Similar result reported by (Sanjeev kapoor, 2001) when studied on pickles and chutney in India.

\section{Conclusion}

The baseline survey of this study showed that all the selected commercial brands of pickles and chutneys are adulterated. According to the laboratory analysis in BSTI and sensory and organoleptic test it was found that all the selected commercial brands of pickles and chutneys are free from adulterants and the products may be recommended as safe and fit for consumption. According to the results obtained from analysis, these products should be recommended as safe for consumption. These two results, one from base line survey and other from laboratory analysis are opposite to each other. However, there is no room for confusion, because our consumers are in darkness about the innate quality and due to lack in their awareness about the quality standards of commercial brands of pickles and chutneys. It can be concluded from the study that in most cases consumer's view towards commercially processed fruit product is wrong. Finally, it is suggested that the government authorized agency such as Bangladesh Council of Scientific and Industrial Research and Bangladesh Standard and Testing Institute should take control and regular monitoring to check physicochemical and microbial quality of processed food. In addition, enforcing law and imposing punishment, social motivation of food processor, adopting BSTI standards, social motivation of food consumers and strengthening supervision by legal authority to control adulteration and improve the quality of commercial fruit products. 


\section{Acknowledgement}

This study was conducted with the financial assistance received from the project entitled- "Coordinated Project on Contaminants and adulterants in food chain and their mitigation: BAU Component" funded by National Agricultural Technology Project Phase-1, Bangladesh Agricultural Research Council, Farmgate, Dhaka.

\section{References}

AOAC. 2005. Official Methods of Analysis of the Association of Analytical Chemists. 15th ed. Arlington. Virginia. (942.15).

Askar, A. and Treptow, H. 1993. Quality Assurance in Tropical Fruit Processing. Springer Laboratory 238 p.

Bangladesh standard specification for pickles and chutney third revision appendix-C, BDS 520., (2012).

BHASIN, U. and B.S. BHATIA. 1981. Recent advances in technology of pickles, chutneys and sauces. Indian Food Packer, 35(1): 39-55.

Chawla, P., Ghai, S. and Sandhu, K.S. 2005. Studies on the nutritional and organoleptic characteristics of carrot pickle during storage. Journal of Food Science and Technology, Mysore, 42(4): 358-360.

$\mathrm{CMH}$. 2005. Maximum levels of contaminants in foods. Chinese Minisiry of Health. GB2762-2005.

Desrosier Norman, W. 1977. "The Technology of Food Preservation". The AVI Publishing co. 2 nd edition West port. USA. PP- 264.

Dhyani, A. and Saklani, A. 1994. To assess awareness of consumers towards consumer protection laws. In. J. Marketing, 23, No. 7, 8, July -August, pp: 9-12.

Gupta, G.K. 1998. Standardization of concentrations of additives for development and processing of oil less mango pickle. Indian Food Packer, vol.4: 15-17.

Hamureu, M., Ozean, M.M., Dursun, N., and Gezgin, S. 2010. Mineral and heavy metal levels of some fruits grown at the road sides. Food and Chemical toxicology. 48, 1767-1770.

Hui,-Y-H. 2004. Handbook of food and beverage fermentation technology. pp 677:693.

Khan, A.H., Tarafdar, S.A., Ali, M., Biswas, S.K. and Maroof, F.B.A. 1989. The status of trace and minor elements in some Bangladeshi foodstuffs. Journal of Radioanalytical and Nuclear Chemistry, 134: 367-381.

Pruthi, J.S. and Bedekar, S.V. 1963. Studies on varietal trials in salting or brining of raw mango slices for subsequent use in chutney and pickle manufacture. The Punjab Horticultural Journal, 3 (2): 264-271.

Ranganna, S. 2005. Handbook of Analysis and Physio-chemical Analysis. Tata Mc Graw Hill Publishing Company Lt. New Delhi, 110-002: 9-10.

Rejano, L., Sanchez, A.H., Cantro, ADE; Montato. 1997. Chemical characteristics and storage stability of garlic pickled prepared using different processes. Journal of Food Science, Spain, 62(6): 1120-1123.

Salunkhe, D.K. and Kadam, S.S. 1995. Handbook of Fruit Science and Technology, Marcel Dekker, New York, pp: 611.

Sanjeev kapoor. 2001. Pickles and chutney in India. Journal food science technology., Vol.5: pp: 203.

Shiblee, S.M.A., Hossain, M.A., Quamruzzaman, A.K.M., Jamil, M.K. and Zaman, M.M.K. 2005. Market research and market linkup of ber and tamarind products for the producers of Gazipur area. Journal of Socioeconomic Research and Development, 2(1): 5-11.

Siddique, F.A., Salah-ud-Din, B.A. Mahmood and F.H. Shah. 1987. Copper, lead, tin and zinc contents in canned and bottled fruit and fruit products. Pak. J. Sci.Ind. Res, 30 (4): 505-510.

Usha Rani, M., Rama Rao, S.N., Girija Bai, R. and Nagaraja, K.V. 1992. Studies on quality standards of Indian commercial pickle, Indian Food Packer, 28(7): 27-33.

Vibha-Verma and Lokendra-Singh. 2005. Screening of different doses of preservatives and spices in pickles in relation to the shelflife. Advances in Plant Sciences, 18(1): 49-54.

Williams,-P, Stirling,-E, Keynes,-N. 2004. Food fears: a national survey on the attitudes of Australian adults about the safety and quality of food, Asia-Pacific-Journal-of-Clinical-Nutrition, 13(1): 32-39.

Zhou-Xiao Ping, Chen-Zhi Jun, Wang-Li Yuan, Wang-Ruo Yan, Pan-GuoShao and Yu-Xin. 2008. Analysis of food contamination caused by lead, cadmium, arsenic and aluminum in Shaoxing city. Disease-Surveillance. 23(2): 100-106. 